\title{
Phenotypic traits of equines raised in the Pantanal of Mato Grosso do Sul
}

\section{Caracterização fenotípica de equídeos criados no Pantanal do Mato Grosso do Sul}

\author{
Julio Cesar de Souza ${ }^{1}$; Marcos Paulo Gonçalves de Rezende ${ }^{2 *}$; \\ Geovane Gonçalves Ramires ${ }^{3}$; Vanessa Terra Gonçalves ${ }^{4}$; Carolina Fregonesi Souza ${ }^{5}$; \\ Nicacia Monteiro de Oliveira ${ }^{6}$; Rodrigo Vedovato Ribeiro ${ }^{7}$
}

\begin{abstract}
The primary aim of this study was to characterize the phenotypes of equines raised in the Pantanal region of Mato Grosso do Sul, one of the central-western states of Brazil. Eighteen linear measurements were collected from 498 adult horses belonging to several different breeds, including Pantaneira ( $\mathrm{n}$ $=52)$, Arabic $(\mathrm{n}=28)$, Crioulo $(\mathrm{n}=31)$, Mangalarga $(\mathrm{n}=8)$, Quarter Horse $(\mathrm{n}=97)$, Petiço $(\mathrm{n}=9)$, Crossbred Horses (i.e., undetermined breeding; $n=170)$, and Mules $(n=74)$. These measurements were compared to similar measurements taken of English Thoroughbreds $(n=14)$ and Brazilian Equestrians $(\mathrm{n}=15)$ in the city of Campo Grande, the capital of Mato Grasso do Sul. We used analysis of variance to test the influence of several factors, including genetic group, category (horse or mule), sex, and their interactive effects, on phenotypic characteristics. Correlation estimates verified the Euclidean distance between genetic groups categorized via cluster analysis. The effects were significant $(\mathrm{P}<0.05)$ for many of the phenotypic characteristics. Horses showed higher values for most of the measurements compared to mules, except for the length of the head, lumbar back length, and cannon bone circumference, as well as greater correlation between weight and heart girth $(\mathrm{r}=0.98)$. Cluster analysis determined that the animals were categorized into nine groups, with 10 distinct populations. Correspondence analysis showed that the Crioulo, Crossbred Horses, Mules, Pantaneiro, and Mangalarga breeds were less distinct phenotypically. The Petiço breed was not grouped, whereas Quarter Horses, English Thoroughbreds, and Brazilian Equestrians were more phenotypically distinct from the other breeds.
\end{abstract}

Key words: Biometrics, Equus, genotypes, morphology, Pantanal region

\section{Resumo}

Objetivou-se caracterizar fenotipicamente os equídeos criados no Pantanal do Mato Grosso do Sul. Mensuraram-se 18 medidas lineares em 498 equídeos adultos pertencentes às raças Pantaneira $(n=52)$,

${ }^{1}$ Biólogo e Zootecnista, Prof. Titular, Universidade Federal do Mato Grosso do Sul, UFMS, Paranaíba, MS, Brasil. E-mail: julio. souza@ufms.com.br

2 Discente do Curso de Doutorado do Programa de Pós-Graduação em Zootecnia, Universidade Estadual do Sudoeste da Bahia, UESB, Itapetinga, BA, Brasil. E-mail: mpgrezende@gmail.com

${ }^{3}$ Discente do Curso de Mestrado do Programa de Pós-Graduação em Zootecnia, UEMS, Aquidauana, MS, Brasil. E-mail: ramires_ ggr@hotmail.com

${ }^{4}$ Discente do Curso de Biologia, UFMS, Aquidauana, MS, Brasil. E-mail: vanessatgonçalves@hotmail.com

5 Pesquisador, Instituição Pré-Objetivo, Paranaíba, MS, Brasil. E-mail: carolinafregonesi7@hotmail.com

${ }^{6}$ Discente do Curso de Zootecnia, UFMS, Campo Grande, MS, Brasil. E-mail: nicaciamon@yahoo.com.br

7 Médico Veterinário, Universidade para o Desenvolvimento do Estado e da Região do Pantanal, UNIDERP, Campo Grande, MS, Brasil. E-mail: marcos_re_z@hotmail.com

* Author for correspondence 
Árabe $(n=28)$, Crioulo $(n=31)$, Mangalarga $(n=8)$, Quarto de Milha $(n=97)$, Petiço $(n=9)$, equinos mestiços $(\mathrm{n}=170)$ e Muares $(\mathrm{n}=74)$.Para realizar distâncias fenotípicas incluiu-se informações das raças Puro Sangue Inglês $(n=14)$ e Brasileiro de Hipismo $(n=15)$, mensurados em Campo GrandeMS. Realizou-se análise de variância para verificar influência dos efeitos de grupo genético, categoria (equino ou muar), sexo, e suas interações; analisaram-se correlações fenotípicas e para verificação da distância euclidiana entre grupos genéticos realizou-se analise de cluster. Os efeitos de variância foram significativos $(\mathrm{P}<0,05)$ em muitas das características fenotípicas. Os equinos em relação aos muares apresentaram valores superiores para maior parte das medidas, exceto para o comprimento de cabeça, comprimento dorso lombar e perímetro de canela. Obtiveram maiores correlações fenotípicas entre peso e perímetro torácico $(\mathrm{r}=0,98)$. A análise de agrupamento possibilitou verificar que os equídeos foram categorizados em 9 grupos, com 10 populações distintas. A análise de correspondência apresentou diferenças menos notáveis em seus padrões fenotípicos entre as raças Crioula, equinos mestiços, Muares, Pantaneiros e Mangalarga. O grupamento Petiço foi o único que tendeu a não se agrupar. As raças Quarto de Milha, Puro Sangue Inglês, Brasileiro de Hipismo apresentam padrões fenotípicos com maior distância em relação aos demais.

Palavras-chave: Biometria, Equus, genótipos, morfologia, região Pantaneira

\section{Introduction}

The Pantanal is a vast plain, $140000 \mathrm{~km}^{2}$ in area, located in the central-western region of Brazil (MISERANI et al., 2002) that is used extensively by wildlife and livestock. This biome features predominantly sandy soils (POTT et al., 1989), periodic flooding (POTT, 1997), and a tropical climate with well-defined dry and wet seasons. Graze is at times both restricted and of poor quality due to the climatic conditions of the area (SANTOS, 1997; SANTOS et al., 2002).

Beef cattle are the main economic resource in the region, for which extensive management systems are common (ABREU et al., 2006; SANTOS et al., 2009; SILVA et al., 2005). Horses are used for managing the cattle, especially in large fields during the wet season, and thus are an important component of these farm systems.

According to Egito et al. (2002), horses of Iberian origin were first introduced to the Pantanal around the year 1534. The authors also report that the unique Pantanal breeds developed as the horses adapted to the unique climatic conditions of the region.

Zúccari et al. (2002) reviewed several studies of the native Pantaneiro equine. In recent years, however, various other breeds have arisen in the region, and research addressing the biometric characteristics of the genotypes of these different types of horses native to the Pantanal is scarce.

Maintaining a breed for long periods contributes to the development of characteristics specific to a certain environment (BICALHO, 1985). In this context, both the pure and crossbred horses bred for adaptation to the environmental conditions of the Pantanal may exhibit phenotypic variation, and knowledge of these differences can be used to aid farmers in selection and breeding of the animals for farm use.

Phenotypic characterization of the various horse breeds can also be critical for identifying the particular skills of each breed, as well as aid in the diagnosis of the qualities and defects of each part of the animal (PARÉS i CASANOVA, 2010; PIMENTEL et al., 2011). Domingues (1960) considers the phenotypic attributes related of the animal, as weights of greater importance in breed profiling and transmissibility.

Studies focusing on the phenotypic characterization of horses have been conducted previously in Brazil (GODOI et al., 2013; KURTZ FILHO; LOF, 2007; MCMANUS etal., 2005; MELO 
et al., 2011, 2013; MISERANI et al., 2002; PINTO et al., 2005; QUIRINO et al., 2012; REZENDE et al., 2014; SANTOS 1993), the information for which was obtained via linear measurements of individuals of various breeds (OOM; FERREIRA, 1987; PARÉS i CASANOVA, 2010; TORRES; GARDEN, 1985).

After establishing, the values related to each feature, statistical tools were applied in order to verify existing variations among individuals and between populations, in order to examine the probability of matching a genetic group or breed (FERNÁNDEZ et al., 1998; RODERO et al., 2003).

The objective of this study was to identify the phenotypic characteristics of horses bred in the Pantanal region of Mato Grosso do Sul, through the analysis of comparative linear measurements.

\section{Material and Methods}

Our research was conducted in partnership with several Pantanal farms in the Aquidauana, Abobral, Rio Negro, Nhecolândia, and Miranda regions of Mato Grosso do Sul, Brazil, which use horses for the management of cattle. Four hundred and ninety eight adult horses belonging to the Pantaneira, Arabic, Crioula, Mangalarga, Quarter Horse, Petiço, Crossbred Horse, and Mule breeds were measured. Measurements of English Thoroughbreds and Brazilian Equestrians were taken in the city of Campo Grande and added to the database for use in estimating phenotypic distances among the various breeds (Table 1).

Table 1. Description of equine measured in different regions of the Pantanal $\left(^{*}\right)$ and in Campo Grande $(* *)$.

\begin{tabular}{lcccccccccc}
\hline \multirow{2}{*}{ Sex } & \multicolumn{10}{c}{ Genetic group } \\
\cline { 2 - 10 } & ARB $^{*}$ & MUA* & CR $^{*}$ & PE* $^{*}$ & QM $^{*}$ & ML* & PAN* & RD $^{*}$ & BH $^{* *}$ & PSI** \\
\hline Female & 17 & 42 & 13 & 5 & 73 & 2 & 23 & 77 & 7 & 5 \\
Male & 11 & 32 & 18 & 4 & 24 & 6 & 29 & 93 & 8 & 9 \\
N & 28 & 74 & 31 & 9 & 97 & 8 & 52 & 170 & 15 & 14 \\
Fr (\%) & 5.62 & 14.85 & 6.22 & 1.8 & 19.47 & 1.6 & 10.44 & 34.13 & 3.01 & 2.81 \\
\hline
\end{tabular}

ARB: Arabic; PSI: Thoroughbred; BH: Brazilian Equestrian; QM: Quarter Horse; CR: Crioulo; RD: Crossbred Horse (No Defined Racial Standard); ML: Mangalarga; MUA: Mules; PAN: Pantaneiro; PE: Petiço.

With the aid of tape and hipometer, taken up in 17 linear steps equine (Figure 1), where the left side of the animal body, positioned with the least possible irregularity in the ground, based on the methods described by Mcmanus et al. (2005), Oom and Ferreira (1987), Parés i Casanova (2010), Rezende et al. (2013) and Torres and Garden (1985). 
Figure 1. Linear measurements taken of the horses. ET: thoracic girth; AC: withers height; CC: body length; CCAB: head length; CP: neck length; EC: shoulder length; CDL: lumbar back length; CG: croup length; AJ: knee height; PJ: perimeter of the knee; AG: hip height; PC: perimeter of the cannon bone; LG: croup width; LP: chest width; AJA: hock height; DCS: elbow distance from the ground; PAB: forearm perimeter; Q: weight.

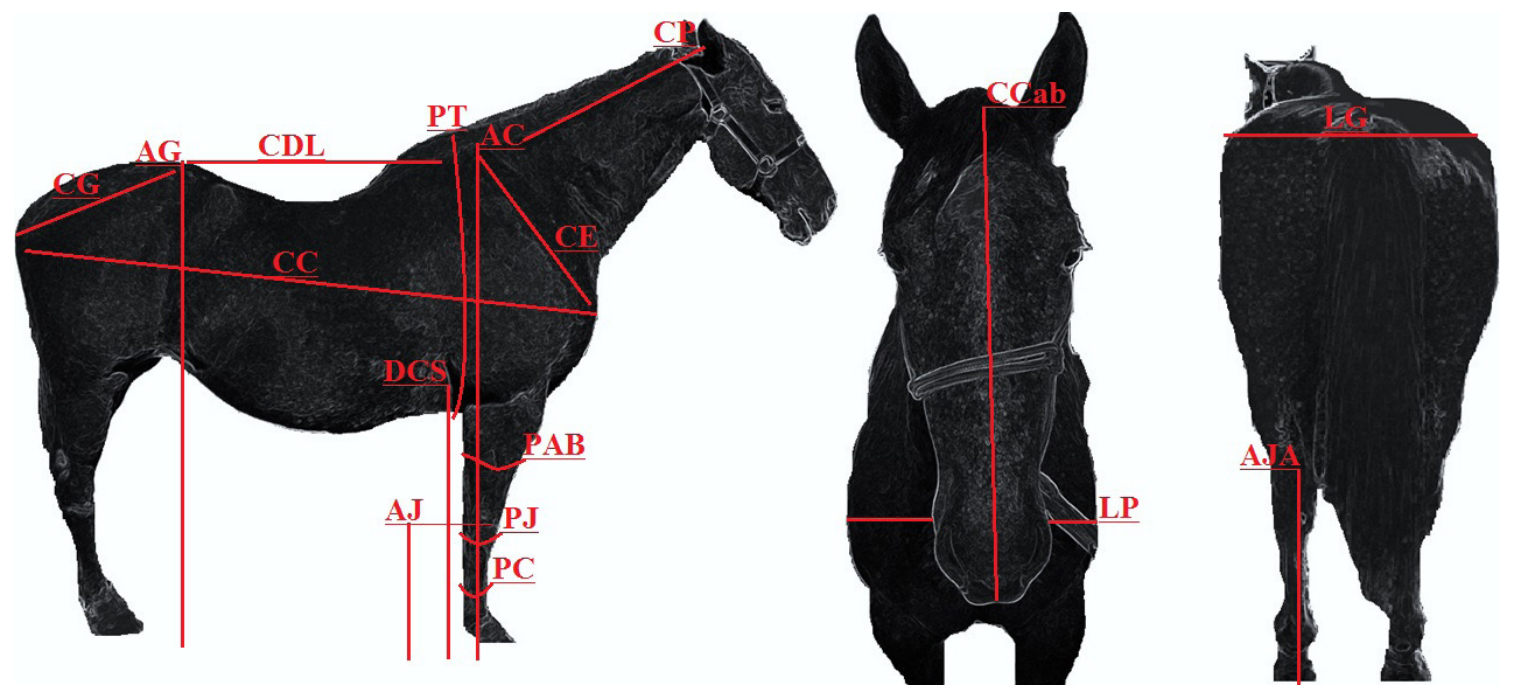

Weight $(\mathrm{P})$ was estimated using the formula: $\mathrm{P}=$ $\mathrm{PT}^{3} \times 80$, where $\mathrm{PT}$ is the heart girth size.

An SAS program was used for statistical analyses of the data. Analysis of variance (ANOVA) was performed to assess the influence of fixed effects on the phenotypic traits (linear measurements) using the GLM procedure. The model included the genetic group effects (Arabic, English Thoroughbreds, Crioulo, Pantaneiro, Petiço, Mangalarga, Brazilian Equestrians, Quarter Horse, Crossbreed Horses, and Mules), category (horse or mule), sex (male and female), and the genetic group $\times$ sex and category $\times$ sex interactions.

Means and standard errors were generated by the ANOVA, with a Tukey's test then used to compare the means. A Pearson correlation coefficient test was used to calculate correlations among the phenotypic characteristics, using the CORR procedure. The Euclidean distance between genetic groups was estimated based on an analysis of the linear measurements (CLUSTER; TREE).

\section{Results and Discussion}

The sources used in the ANOVA accounted for differences between many of the phenotypic traits we examined (Table 2). The coefficient of variation $(\mathrm{CV})$ was less than $10 \%$ for most of the characteristics that were analyzed, with higher values found for weight $(\mathrm{CV}=22.54 \%)$, chest width $(\mathrm{CV}=11.92 \%)$, and croup length $(\mathrm{CV}=11.67 \%)$, whereas less significant values were found for croup height $(\mathrm{CV}=5.41 \%)$, body length $(\mathrm{CV}=5.72 \%)$, and hip height $(\mathrm{CV}=6.04 \%)$. 
Table 2. Summary of equine ANOVA.

\begin{tabular}{lccccccccc}
\hline & $\mathrm{PT}$ & $\mathrm{AC}$ & $\mathrm{CC}$ & $\mathrm{CCab}$ & $\mathrm{CP}$ & $\mathrm{CE}$ & $\mathrm{CDL}$ & $\mathrm{CG}$ & $\mathrm{AJ}$ \\
\hline $\mathrm{SX}$ & $* *$ & $* * *$ & $* *$ & $*$ & $\mathrm{~ns}$ & $\mathrm{~ns}$ & $\mathrm{~ns}$ & $\mathrm{~ns}$ & $\mathrm{~ns}$ \\
$\mathrm{CAT}$ & $* *$ & $* *$ & $* *$ & $* *$ & $* *$ & $*$ & $* *$ & $* *$ & $* *$ \\
$\mathrm{GG}$ & $* * *$ & $* * *$ & $* * *$ & $* * *$ & $* * *$ & $* * *$ & $* * *$ & $* * *$ & $* * *$ \\
$\mathrm{SX}$ GG & $* * *$ & $* * *$ & $* * *$ & $* *$ & $* * *$ & $* * *$ & $* * *$ & $* * *$ & $* * *$ \\
$\mathrm{SX}$ CAT & $* *$ & $* *$ & $* *$ & $* *$ & $* *$ & $* *$ & $* *$ & $* *$ & $* *$ \\
\hline Med & 176.98 & 145.12 & 145.46 & 62.61 & 60.00 & 52.62 & 56.00 & 47.15 & 44.37 \\
$\mathrm{~S}$ & 158.35 & 76.72 & 69.28 & 18.75 & 40.47 & 31.14 & 28.77 & 30.26 & 15.71 \\
$\mathrm{E} . \mathrm{P}$ & 0.56 & 0.39 & 0.37 & 0.19 & 0.29 & 0.25 & 0.24 & 0.25 & 0.18 \\
$\mathrm{CV}$ & $7.11 \%$ & $6.04 \%$ & $5.72 \%$ & $6.92 \%$ & $10.60 \%$ & $10.60 \%$ & $9.58 \%$ & $11.67 \%$ & $8.93 \%$ \\
\hline & $\mathrm{PJ}$ & $\mathrm{AG}$ & $\mathrm{PC}$ & $\mathrm{LG}$ & $\mathrm{LP}$ & $\mathrm{AJA}$ & $\mathrm{DCS}$ & $\mathrm{PAB}$ & $\mathrm{P}$ \\
\hline $\mathrm{SX}$ & $\mathrm{ns}$ & $\mathrm{ns}$ & $\mathrm{ns}$ & $* *$ & $\mathrm{~ns}$ & $\mathrm{~ns}$ & $\mathrm{~ns}$ & $* *$ & $* *$ \\
$\mathrm{CAT}$ & $* *$ & $* *$ & $\mathrm{~ns}$ & $* *$ & $* *$ & $* *$ & $* *$ & $* *$ & $* *$ \\
$\mathrm{GG}$ & $* * *$ & $* * *$ & $* * *$ & $* * *$ & $* * *$ & $* * *$ & $* * *$ & $* * *$ & $* * *$ \\
$\mathrm{SX}$ GG & $* * *$ & $* * *$ & $* * *$ & $* * *$ & $* * *$ & $* * *$ & $* * *$ & $* * *$ & $* * *$ \\
$\mathrm{SX}$ CAT & $*$ & $* *$ & $\mathrm{~ns}$ & $* *$ & $* *$ & $* *$ & $* *$ & $* *$ & $* *$ \\
\hline Med & 30.61 & 144.08 & 20.06 & 49.11 & 36.83 & 52.29 & 85.38 & 46.90 & 450.49 \\
$\mathrm{~S}$ & 6.20 & 60.87 & 4.24 & 13.71 & 19.29 & 26.59 & 64.70 & 24.87 & 10306.42 \\
$\mathrm{E} . \mathrm{P}$ & 0.11 & 0.35 & 0.09 & 0.17 & 0.20 & 0.23 & 0.36 & 0.22 & 4.54 \\
$\mathrm{CV}$ & $8.14 \%$ & $5.41 \%$ & $10.27 \%$ & $7.54 \%$ & $11.92 \%$ & $9.86 \%$ & $9.42 \%$ & $10.63 \%$ & $22.54 \%$ \\
\hline
\end{tabular}

$* \mathrm{P}<0.05 ; * * \mathrm{P}<0.01 ; * * * \mathrm{P}<0.0001$; ns: not significant; $\mathrm{SX}$ : sex; GG: genetic group, CAT: category; Med: mean; S: variance; E.P: standard error; CV: coefficient of variation; ET: thoracic girth; AC: withers height; CC: body length; CCAB: head length; CP: neck length; EC: shoulder length; CDL: lumbar back length; CG: croup length; AJ: knee height; PJ: perimeter of the knee; AG: hip height; PC: perimeter of the cannon bone; LG: croup width; LP: chest width; AJA: hock height; DCS: elbow distance from the ground; PAB: forearm perimeter; Q: weight.

Mawdsley et al. (1996) and McManus et al. (2005), who studied the linear measurements of English Thoroughbreds and Campeiros, respectively, calculated CVs greater than $10 \%$ for most traits. Our results, however, are more in line with those observed by Miserani et al. (2002), Rezende et al. (2014), and Vassiley and Sabeva (1996), who reported lower CV values for Pantaneiro, Crossbreed Horses, a variety of different breeds, and crosses of English Thoroughbred with Monta equine West of Bulgaria, respectively.

The effect of gender was significant for head length $(\mathrm{P}<0.05)$; for heart girth, body length, croup width, forearm circumference, and weight ( $\mathrm{P}$ $<0.01)$; and for withers height $(\mathrm{P}<0.0001)$. The category effects and sex $\times$ category interaction was not significant $(\mathrm{P}>0.05)$ for cannon circumference only, whereas the genetic group effect and $\operatorname{sex} x$ genetic group interaction was significant $(\mathrm{P}<0.05)$ for all measurements.

Miserani et al. (2002) studied factors that influence the linear measurements of Pantaneiro horses and found a significant effect of gender for all traits. Campos et al. (2007) observed significant differences in just a few features in studies of the equine herd of the Brazilian Army. Kurtz Filho and Lof (2007), Miserani et al. (2002), and Rezende et al. (2014), studying equine Crioulos, Pantaneiro, and horses of different breeds, respectively, observed both sex and breed effects on the linear measurements.

Mares were found to have measurement values similar to those of males, indicating that females 
can also be used for work, except when nursing.

This type of management can provide a number of benefits to the owner, including reducing the size of the horse herd given that females do not have to be used exclusively for reproduction, reducing financial costs, and increasing knowledge about the nature of the dam. This information can be used as selection criteria in decision making when females enter the mating season.
When comparing effects between categories, it was observed that horses had higher values for all of the phenotypic traits than did mules, with the exceptions of head length, lumbar back length, and circumference of the cannon bone, with an average difference of $2.23 \mathrm{~cm}, 3.14 \mathrm{~cm}$, and $0.14 \mathrm{~cm}$, respectively, in relation the mule (Table 3). Overall, horses were taller, longer, and wider than mules; however, body weight was about the same for both horses and mules (between $350 \mathrm{~kg}$ and $550 \mathrm{~kg}$ ).

Table 3. Average of least squares means and their standard errors of phenotypic traits according to category, where Med. I $=$ horses and Med. II $=$ mules.

\begin{tabular}{lccccccccc}
\hline & PT & AC & CC & CCab & CP & CE & CDL & CG & AJ \\
\hline Med.I & $177.91^{\mathrm{A}}$ & $146.17^{\mathrm{A}}$ & $146.28^{\mathrm{A}}$ & $62.28^{\mathrm{A}}$ & $60.41^{\mathrm{A}}$ & $52.88^{\mathrm{A}}$ & $55.54^{\mathrm{A}}$ & $48.04^{\mathrm{A}}$ & $44.77^{\mathrm{A}}$ \\
E.P & \pm 0.62 & \pm 0.42 & \pm 0.40 & \pm 0.20 & \pm 0.31 & \pm 0.27 & \pm 0.25 & \pm 0.24 & \pm 0.19 \\
Med.II & $171.70^{\mathrm{B}}$ & $139.07^{\mathrm{B}}$ & $140.73^{\mathrm{B}}$ & $64.51^{\mathrm{B}}$ & $57.69^{\mathrm{B}}$ & $51.12^{\mathrm{B}}$ & $58.68^{\mathrm{B}}$ & $42.07^{\mathrm{B}}$ & $\pm 42.09^{\mathrm{B}}$ \\
E.P & \pm 1.20 & \pm 0.86 & \pm 0.89 & \pm 0.61 & \pm 0.68 & \pm 0.62 & \pm 0.64 & \pm 0.66 & \pm 0.39 \\
\hline & PJ & AG & PC & LG & LP & AJA & DCS & PAB & P \\
\hline Med.I & $30.73^{\mathrm{A}}$ & $145.05^{\mathrm{A}}$ & $20.04^{\mathrm{A}}$ & $49.57^{\mathrm{A}}$ & $37.22^{\mathrm{A}}$ & $52.88^{\mathrm{A}}$ & $86.02^{\mathrm{A}}$ & $47.46^{\mathrm{A}}$ & $457.78^{\mathrm{A}}$ \\
E.P & \pm 0.12 & \pm 0.37 & \pm 0.09 & \pm 0.17 & \pm 0.21 & \pm 0.25 & \pm 0.39 & \pm 0.24 & \pm 5.07 \\
Med.II & $29.92^{\mathrm{B}}$ & $138.53^{\mathrm{B}}$ & $20.18^{\mathrm{A}}$ & $46.46^{\mathrm{B}}$ & $34.59^{\mathrm{B}}$ & $48.86^{\mathrm{B}}$ & $81.72^{\mathrm{B}}$ & $43.72^{\mathrm{B}}$ & $408.75^{\mathrm{B}}$ \\
E.P & \pm 0.32 & \pm 0.75 & \pm 0.32 & \pm 0.45 & \pm 0.40 & \pm 0.50 & \pm 0.80 & \pm 0.46 & \pm 8.15 \\
\hline
\end{tabular}

Different superscripted letters indicate statistical significance (Tukey's test, $\mathrm{P}=0.05$ ). E.P: standard error. PT: thoracic girth; AC: withers height; CC: body length; CCAB: head length; CP: neck length; EC: shoulder length; CDL: lumbar back length; CG: croup length; AJ: knee height; PJ: perimeter of the knee; AG: hip height; PC: perimeter of the cannon bone; LG: croup width; LP: chest width; AJA: hock height; DCS: elbow distance from the ground; PAB: forearm perimeter; Q: weight.

The highest values were observed in the posterior region of the horses, including croup length, hock height, hip height, and width of croup, which contributes to their greater speed (GONÇALVES et al., 2011). Moreover, a longer shoulder length benefits the rear quarters, as it provides the animal with greater flexibility (INGLÊS, 2004).

Considering the body proportions of the animals, the lower values for lumbar back length in horses and the longer shoulder and croup lengths, in addition to the greater chest width, may favor horses over mules when it comes to work longevity.

It was observed that, when comparing the phenotypic profiles of the genetic groups, Brazilian
Equestrians and English Thoroughbreds were both taller and longer than the other breeds. The Pantaneira and Crioulo breeds were very similar in all phenotypic respects, whereas the Petiço generally exhibited lower values (Table 4).

Brazilian Equestrians, Quarter Horses, English Thoroughbreds, Arabians, and Mangalargas all exhibited higher values for heart girth, thoracic and locomotor members, perimeter, and height. These are measurements of the anatomical parts of the body that support the mass of the animals (PINTO et al., 2005). These genetic groups also had higher values for estimated body weight.

Whereas animals with greater height in relation 
to body length have greater ability to service the saddle and the back of the loin region is loadbearing point that the animal must carry, it has been found greater ability for load based on values the height measurements, body length and lumbar back, for genetic grouping Petiço, Quarter Horses, Mules, Pantaneiro and Crioulo, in relation to the other. Fitness is important for animals that are used in daily work for managing cattle in the Pantanal, given that most farming systems cover extensive areas.

It is noteworthy that the back line along the loin must be proportional to the chest-abdomen circumference, in order to maximize balance. This body balance is also related to the strength of the hind legs, well-sprung ribs, and a broad, well-muscled chest, which also contributes to the development of cardiorespiratory ability (THOMAS, 2005), in addition to improving the mechanical transmission performance of caudal-cranial propulsion forces. However, a very short back is less desirable because it may compromise body flexibility and elasticity (JONES, 1987).

Balance is the basis of all movements that affect performance. According to Pinto et al. (2005), the neck is used by horses to shift the center of gravity horizontally. Our results suggest that the Crioulo, English Thoroughbred, Mangalarga, and Petiço breeds should exhibit a superior sense of balance, as indicated by their neck length in proportion to other body measurements (chest width, croup width, body length). Finer balance not only reduces the chances of injury to the animals, but also improves the comfort level of the rider.

Crioulos, English Thoroughbreds, Mangalargas, and Petiços exhibited higher balance-related values, based on chest width and croup width measurements, which enable better control of the displacement of the center of gravity of the body (PINTO et al., 2005). Adams and Perry (1998) reinforce the swing in biomechanical attributes in animals, is a propulsion leg.

Table 4. Average of least squares means and standard errors of phenotypic traits according to the genetic groups.

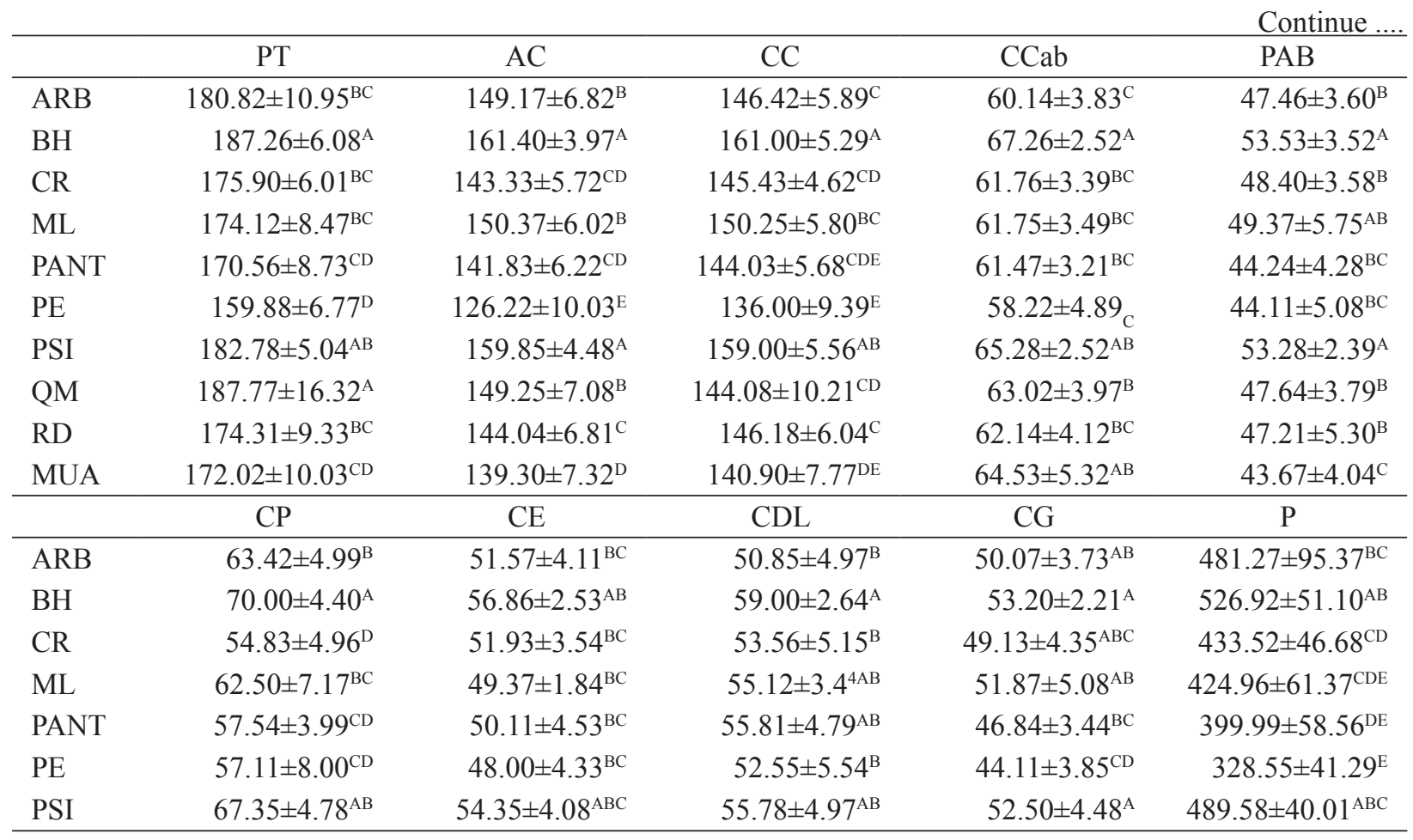




\begin{tabular}{|c|c|c|c|c|c|}
\hline QM & $63.32 \pm 7.20^{\mathrm{B}}$ & $56.93 \pm 6.73^{\mathrm{A}}$ & $57.04 \pm 5.06^{\mathrm{A}}$ & $46.48 \pm 5.30^{\mathrm{BC}}$ & $541.80 \pm 47.71^{\mathrm{A}}$ \\
\hline $\mathrm{RD}$ & $58.74 \pm 4.56^{\mathrm{C}}$ & $51.72 \pm 4.78^{\mathrm{BC}}$ & $55.58 \pm 5.06^{\mathrm{AB}}$ & $47.86 \pm 4.97^{\mathrm{BC}}$ & $428.06 \pm 65.56^{\mathrm{CD}}$ \\
\hline \multirow[t]{2}{*}{ MUA } & $57.84 \pm 5.92^{\mathrm{CD}}$ & $51.35 \pm 5.17^{\mathrm{BC}}$ & $58.78 \pm 5.58^{\mathrm{A}}$ & $42.02 \pm 5.78^{\mathrm{D}}$ & $410.81 \pm 68.49^{\mathrm{CDE}}$ \\
\hline & $\mathrm{AJ}$ & PJ & $\mathrm{AG}$ & $\mathrm{PC}$ & \\
\hline $\mathrm{ARB}$ & $46.39 \pm 2.62^{\mathrm{B}}$ & $29.71 \pm 0.93^{\mathrm{BC}}$ & $148.82 \pm 5.43^{\mathrm{B}}$ & $18.82 \pm 0.81^{\mathrm{CD}}$ & \\
\hline $\mathrm{BH}$ & $51.06 \pm 2.25^{\mathrm{A}}$ & $33.86 \pm 4.22^{\mathrm{A}}$ & $161.00 \pm 3.68^{\mathrm{A}}$ & $21.00 \pm 0.92^{\mathrm{AB}}$ & \\
\hline $\mathrm{CR}$ & $42.46 \pm 2.30^{\mathrm{C}}$ & $31.03 \pm 1.88^{\mathrm{B}}$ & $141.36 \pm 4.81^{\mathrm{CDE}}$ & $20.13 \pm 1.35^{\mathrm{BC}}$ & \\
\hline ML & $44.75 \pm 3.61^{\mathrm{BC}}$ & $30.75 \pm 1.90^{\mathrm{BC}}$ & $148.50 \pm 5.90^{\mathrm{BC}}$ & $19.50 \pm 1.30^{\mathrm{BCD}}$ & \\
\hline PANT & $42.66 \pm 3.09^{\mathrm{C}}$ & $29.30 \pm 1.30^{\mathrm{C}}$ & $141.30 \pm 5.43^{\mathrm{DE}}$ & $19.05 \pm 0.86^{\mathrm{CD}}$ & \\
\hline PE & $37.00 \pm 4.03^{\mathrm{D}}$ & $27.66 \pm 1.93^{\mathrm{C}}$ & $127.33 \pm 9.21^{\mathrm{F}}$ & $17.88 \pm 1.36^{\mathrm{D}}$ & \\
\hline PSI & $50.78 \pm 2.69^{\mathrm{A}}$ & $31.92 \pm 1.81^{\mathrm{AB}}$ & $160.00 \pm 4.27^{\mathrm{A}}$ & $20.00 \pm 2.57^{\mathrm{BCD}}$ & \\
\hline QM & $46.76 \pm 4.12^{\mathrm{B}}$ & $32.54 \pm 2.67^{\mathrm{A}}$ & $146.00 \pm 5.90^{\mathrm{BC}}$ & $21.84 \pm 2.37^{\mathrm{A}}$ & \\
\hline $\mathrm{RD}$ & $43.77 \pm 2.49^{\mathrm{C}}$ & $30.04 \pm 1.65^{\mathrm{BC}}$ & $143.69 \pm 5.59^{\mathrm{CD}}$ & $19.56 \pm 1.29^{\mathrm{BCD}}$ & \\
\hline \multirow[t]{2}{*}{ MUA } & $42.14 \pm 3.41^{\mathrm{C}}$ & $29.97 \pm 2.79^{\mathrm{BC}}$ & $138.70 \pm 6.50^{\mathrm{E}}$ & $20.25 \pm 2.80^{\mathrm{B}}$ & \\
\hline & LG & LP & AJA & DCS & \\
\hline ARB & $51.14 \pm 2.56^{\mathrm{AB}}$ & $37.71 \pm 4.14^{\mathrm{BC}}$ & $54.21 \pm 3.17^{\mathrm{BC}}$ & $86.78 \pm 4.69^{\mathrm{C}}$ & \\
\hline $\mathrm{BH}$ & $54.20 \pm 2.42^{\mathrm{A}}$ & $43.46 \pm 3.29^{\mathrm{A}}$ & $60.86 \pm 3.31^{\mathrm{A}}$ & $97.26 \pm 3.73^{\mathrm{A}}$ & \\
\hline $\mathrm{CR}$ & $50.10 \pm 1.97^{\mathrm{BC}}$ & $35.83 \pm 2.84^{\mathrm{CD}}$ & $50.43 \pm 3.57^{\mathrm{DE}}$ & $79.30 \pm 5.77^{\mathrm{CD}}$ & \\
\hline ML & $50.00 \pm 2.13^{\mathrm{BCD}}$ & $36.25 \pm 3.10^{\mathrm{BCD}}$ & $54.00 \pm 5.20^{\mathrm{BCD}}$ & $87.25 \pm 5.67^{\mathrm{BC}}$ & \\
\hline PANT & $48.69 \pm 2.61^{\mathrm{CD}}$ & $34.71 \pm 3.46^{\mathrm{D}}$ & $51.37 \pm 3.22^{\mathrm{CDE}}$ & $82.03 \pm 4.43^{\mathrm{C}}$ & \\
\hline PE & $46.44 \pm 2.35^{\mathrm{D}}$ & $32.22 \pm 3.34^{\mathrm{D}}$ & $46.88 \pm 4.34^{\mathrm{E}}$ & $73.66 \pm 5.85^{\mathrm{D}}$ & \\
\hline PSI & $52.78 \pm 2.00^{\mathrm{AB}}$ & $39.64 \pm 2.20^{\mathrm{B}}$ & $59.78 \pm 4.47^{\mathrm{A}}$ & $95.57 \pm 3.39^{\mathrm{AB}}$ & \\
\hline QM & $47.67 \pm 4.01^{\mathrm{D}}$ & $40.14 \pm 5.13^{\mathrm{B}}$ & $54.72 \pm 5.46^{\mathrm{B}}$ & $91.94 \pm 9.78^{\mathrm{AB}}$ & \\
\hline $\mathrm{RD}$ & $49.94 \pm 3.19^{\mathrm{BCD}}$ & $36.08 \pm 3.19^{\mathrm{CD}}$ & $51.49 \pm 4.31^{\mathrm{CD}}$ & $83.69 \pm 5.04^{\mathrm{C}}$ & \\
\hline MUA & $46.49 \pm 3.88^{\mathrm{D}}$ & $34.56 \pm 3.54^{\mathrm{D}}$ & $48.85 \pm 4.30^{\mathrm{DE}}$ & $82.00 \pm 6.86^{\mathrm{C}}$ & \\
\hline
\end{tabular}

Different superscripted letters indicate signifance (Tukey's test, $\mathrm{P}=0.05$ ). ARB: Arabic; PSI: Thoroughbred; BH: Brazilian Equestrian; QM: Quarter Horse; CR: Crioulo; RD: Crossbred Horse (No Defined Racial Standard); ML: Mangalarga; MUA: Mules; PAN: Pantaneiro; PE: Grouping Genetic Petiço; PT: thoracic girth; AC: withers height; CC: body length; CCAB: head length; CP: neck length; EC: shoulder length; CDL: lumbar back length; CG: croup length; AJ: knee height; PJ: perimeter of the knee; AG: hip height; PC: perimeter of the cannon bone; LG: croup width; LP: chest width; AJA: hock height; DCS: elbow distance from the ground; PAB: forearm perimeter; Q: weight.

As Pinto et al. (2005) noted, the strength of the animals is related to a balanced stem and can be checked by means of proportional action, such as chest width, the length of the croup, and body length and girth, values for which Petiço, Pantaneiro, and Mules displayed lower averages than the other groups. Jones (1987) emphasized that there is a relationship between the depth and width of the breast and the resistance of the animal, as wide pectoral region indicates the presence of well-developed lungs and chest muscles (NASCIMENTO, 1999).
Pinto et al. (2005) also pointed out that the main function of the hindquarters of a horse is to generate the force required for propulsion. Jones (1987) demonstrated that the scapula acts on the force generated by turning further in displacement capacity. It was observed that Mangalarga, Mules, Arabic, and Pantaneiro exhibited similar anatomical measurements involved in that feature (shoulder length, croup width, and body length).

Correlations between the phenotypic traits of horses (Table 5) showed higher values for weight and heart girth $(\mathrm{r}=0.98)$, withers height and hip 
height $(\mathrm{r}=0.91)$, and knee height and elbow distance from the ground $(\mathrm{r}=0.79)$, all of which were highly positively correlated and highly significant ( $<<0.0001)$. Based on these, both measures will have similar response to be observed, which is important for the designer to select animals based on phenotypic traits, monitoring the direct and indirect correlations.

Table 5. Phenotypic correlations of the equine breeds.

\begin{tabular}{|c|c|c|c|c|c|c|c|c|c|}
\hline & PT & $\mathrm{AC}$ & $\mathrm{CC}$ & $\mathrm{CCab}$ & $\mathrm{CP}$ & $\mathrm{CE}$ & $\mathrm{CDL}$ & $\mathrm{CG}$ & AJ \\
\hline $\mathrm{AC}$ & $0.62 * * *$ & & & & & & & & \\
\hline $\mathrm{CC}$ & $0.24 * * *$ & $0.58 * * *$ & & & & & & & \\
\hline Ccab & $0.22 * * *$ & $0.33 * * *$ & $0.34 * * *$ & & & & & & \\
\hline $\mathrm{CP}$ & $0.58 * * *$ & $0.63 * * *$ & $0.41 * * *$ & $0.35^{* * *}$ & & & & & \\
\hline $\mathrm{CE}$ & $0.56^{* * *}$ & $0.53 * * *$ & $0.29 * * *$ & $0.40 * * *$ & $0.48 * * *$ & & & & \\
\hline $\mathrm{CDL}$ & $0.13 * *$ & $0.10^{*}$ & $0.29 * * *$ & $0.52 * * *$ & $0.16 * *$ & $0.40 * * *$ & & & \\
\hline $\mathrm{CG}$ & $0.11 *$ & $0.43 * * * *$ & $0.44 * * *$ & -0.07 & $0.13 * *$ & -0.06 & $-0.26^{* *}$ & & \\
\hline AJ & $0.53 * * *$ & $0.76^{* * *}$ & $0.43^{* * *}$ & $0.32 * * *$ & $0.56^{* * *}$ & $0.53 * * *$ & $0.19 * * *$ & $0.21 * * *$ & \\
\hline PJ & $0.62 * * *$ & $0.61 * * *$ & $0.29 * * *$ & $0.40 * * *$ & $0.53 * * *$ & $0.61 * * *$ & $0.29 * * *$ & 0.04 & $0.60 * * *$ \\
\hline $\mathrm{AG}$ & $0.49 * * *$ & $0.91 * * *$ & $0.66^{* * *}$ & $0.33 * * *$ & $0.58 * * *$ & $0.42 * * *$ & $0.14 * *$ & $0.49 * * *$ & $0.73 * * *$ \\
\hline $\mathrm{PC}$ & $0.57 * * *$ & $0.45^{* * *}$ & $0.14 * *$ & $0.43 * * *$ & $0.46^{* * *}$ & $0.61 * * *$ & $0.35 * * *$ & $-0.13 * *$ & $0.47 * * *$ \\
\hline LG & $0.17 * *$ & $0.46^{* * *}$ & $0.63 * * *$ & $0.18 * * *$ & $0.18 * * *$ & $0.12 * *$ & $0.13 * *$ & $0.56^{* * *}$ & $0.27 * * *$ \\
\hline LP & $0.65^{* * *}$ & $0.58 * * *$ & $0.31 * * *$ & $0.26^{* * *}$ & $0.53 * * *$ & $0.59 * * *$ & $0.16^{* *}$ & $0.22 * * *$ & $0.56 * * *$ \\
\hline AJA & $0.42 * * *$ & $0.64 * * *$ & $0.36^{* * *}$ & $0.19 * * *$ & $0.42 * * *$ & $0.36 * * *$ & 0.05 & $0.32 * * *$ & $0.62 * * *$ \\
\hline ACS & $0.55 * * *$ & $0.70 * * *$ & $0.31 * * *$ & $0.39 * * *$ & $0.55^{* * *}$ & $0.58 * * *$ & $0.33^{* * *}$ & 0.07 & $0.79 * * *$ \\
\hline РАB & $0.30 * * *$ & $0.49 * * *$ & $0.40 * * *$ & 0.07 & $0.33 * * *$ & $0.19 * * *$ & -0.08 & $0.47 * * *$ & $0.41 * * *$ \\
\hline \multirow[t]{2}{*}{$\mathrm{P}$} & $0.98 * * *$ & $0.58 * * *$ & $0.19 * * *$ & $0.19 * * *$ & $0.57 * * *$ & $0.54 * * *$ & 0.10 & 0.08 & $0.51 * * *$ \\
\hline & $\mathrm{PJ}$ & $\mathrm{AG}$ & $\mathrm{PC}$ & $\mathrm{LG}$ & LP & AJA & DCS & PAB & \\
\hline $\mathrm{AG}$ & $0.49 * * *$ & & & & & & & & \\
\hline $\mathrm{PC}$ & $0.78 * * *$ & $0.28 * * *$ & & & & & & & \\
\hline LG & $0.10^{*}$ & $0.57 * * *$ & -0.03 & & & & & & \\
\hline LP & $0.59 * * *$ & $0.52 * * *$ & $0.49 * * *$ & $0.26 * * *$ & & & & & \\
\hline AJA & $0.43 * * *$ & $0.63 * * *$ & $0.32 * * *$ & $0.27 * * *$ & $0.45 * * *$ & & & & \\
\hline ACS & $0.63 * * *$ & $0.62 * * *$ & $0.58 * * *$ & $0.16^{* *}$ & $0.54 * * *$ & $0.64 * * *$ & & & \\
\hline PAB & $0.34 * * *$ & $0.52 * * *$ & $0.17 * *$ & $0.45 * * *$ & $0.41 * * *$ & $0.41 * * *$ & $0.32 * * *$ & & \\
\hline $\mathrm{P}$ & $0.61 * * *$ & $0.45^{* * *}$ & $0.57 * * *$ & $0.12 * *$ & $0.64 * * *$ & $0.41 * * *$ & $0.53 * * *$ & $0.27 * * *$ & \\
\hline
\end{tabular}

$* \mathrm{P}<0,05 ; * * \mathrm{P}<0,01 ; * * * \mathrm{P}<0,0001$. PT: thoracic girth; AC: withers height; $\mathrm{CC}$ : body length; CCAB: head length; CP: neck length; EC: shoulder length; CDL: lumbar back length; CG: croup length; AJ: knee height; PJ: perimeter of the knee; AG: hip height; PC: perimeter of the cannon bone; LG: croup width; LP: chest width; AJA: hock height; DCS: elbow distance from the ground; PAB: forearm perimeter; Q: weight.

Correlations between lengths were moderate $(\mathrm{r}=0.25)$, whereas higher values $(\mathrm{r}=0.75)$ were observed between head length and lower-back torso length. There was also only moderate correlation between breast width and croup width among the breeds $(\mathrm{r}=0.26)$. Perimeter measurements displayed moderate correlations $(r=0.46)$, with higher values found for knee perimeter and cannon bone perimeter $(\mathrm{r}=0.78)$. The correlation values calculated for measurements of height were moderate to high ( $\mathrm{r}$ 
$=0.70$ ), but higher for withers height, croup height, and withers height $(\mathrm{r}=0.91)$.

Ranked correlations between lengths, heights, and widths were medium to moderate $(\mathrm{r}=0.39)$. No significant differences $(\mathrm{P}>0.05)$ were found for the phenotypic correlation length with head croup length and length of the shoulder; lumbar back length with hock height, forearm perimeter, and weight; length of croup with height of elbow from the ground and weight; and finally cannon perimeter with wide croup. Miserani et al. (2002) and Vassiley and Sabeva (1996), when analyzing Pantaneiro and East Bulgarian horses, found correlations for lengths and heights, and low to medium values for perimeter and width measurements $(r=0.40$ and $r$ $=0.40)$.

By using the hierarchical clustering method, it was possible to establish nine groups of 10 distinct populations (Figure 2). The correspondence analysis showed smaller phenotypic differences between Crioulo and Crossbreed Horses, and between Mules and Pantaneiro horses, in both cases average differences were smaller than 0.20 (20\%), suggesting that Crioulo and Pantaneiro stallions are used more often in the breeding of work horses in the Pantanal.

Figure 2. Dendogram of the linear measurements of the genetic groups of horse breeds raised in the Pantanal region. ARB: Arabic; PSI: Thoroughbred; BH: Brazilian Equestrian; QM: Quarter Horse; CR: Crioulo; RD: Crossbred Horse (No Defined Racial Standard); ML: Mangalarga; MUA: Mules; PAN: Pantaneiro; PE: Petiço.

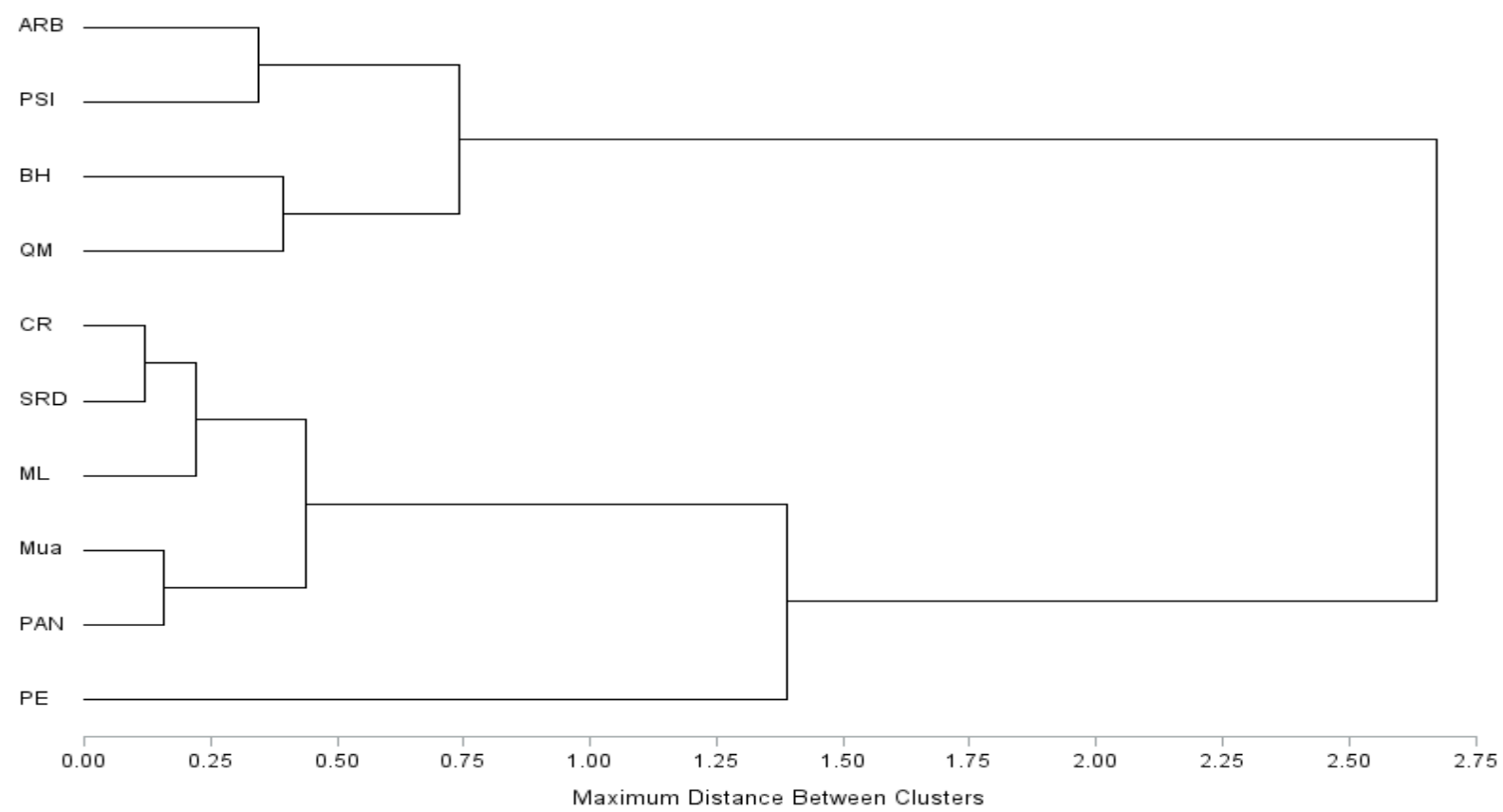

There was a lower inertia $(0.45,45 \%)$ among the phenotypic profiles of the Crioulo, Mangalarga, and Pantaneiro breeds, which is similar to that observed by Cothran et al. (1998), who compared Pantaneiro horses with 52 other domestic horse breeds, including Arab Quarter Horses and Thoroughbreds.
Of all the genotypes, the Petiço group was the primary outlier. They divided two groups with higher amounts of approximately bootstrap 0.75 $(75 \%)$ and $1.40(140 \%)$, where the first group consisted of Arabics, Thoroughbreds, Brazilian Equestrians, and Quarter Horses (a group showing greater robustness in height and body size), whereas 
the second group consisted of the other breeds. This factor (analysis) confirms the body shape difference among the breeds in each group.

\section{Conclusion}

Gender (male or female), category (mules or horses), and breed type are important factors to be considered when making comparisons between the phenotypic profiles of horses bred in the Pantanal. Phenotypic profiles were more similar among horses and mules without defined breed, and the Crioulo, Pantaneiro, and Mangalarga breeds, suggesting the greater use of these types in the Pantanal.

Analyzing variations in the phenotypic profile among genetic groups provides farmers with information about breeding selection based on the environment, type, and intensity of activity that the animals will be used for, thereby contributing to farmers' economic productivity in the Pantanal.

\section{References}

ABREU, U. G. P.; LOPES, P. S.; TORRES, R. A.; SANTOS, H. N. Evaluation of new management technologies on the performance and culling rate of Pantanal beef cows. Revista Brasileira de Zootecnia, Brasília, v. 35, n. 6, p. 2496-2503, 2006.

ADAMS, J. M.; PERRY, J. Gait analysis: clinical application. In: ROSE, J.; GAMBLE, J. G. Marcha humana. $2^{\text {th }}$ ed. São Paulo: Premier, 1998. cap. 7, p.147174.

BICALHO, H. M. S. Grupos sanguíneos e polimorfismos de proteínas do sangue da raça Caracu (Bos taurus taurus).1985. Dissertação (Mestrado em Zootecnia) Universidade Federal de Minas Gerais, Belo Horizonte.

CAMPOS, V. A. L.; MCMANUS, C.; FUCK, B. H. Genetic and environmental effects on production traits of an equine herd of the Brazilian army. Revista Brasileira de Zootecnia, Brasília, v. 36, n. 1, p. 23-31, 2007.

COTHRAN, E. G.; SANTOS, S. A.; MAZZA, M. C. M.; LEAR, T. L.; SERENO, J. R. B. Genetics of the Pantaneiro horse of the Pantanal region of Brazil. Genetics and Molecular Biology, Ribeirão Preto, v. 21, n. 3, p. 343-349, 1998.
DOMINGUES, O. The race husbandry and other groups. In: Introduction to Animal Science. $2^{\text {th }}$ ed. Rio de Janeiro: Ministry of Agriculture, 1960. 169 p.

EGITO, A. A.; MARIANTE, A. S.; ALBUQUERQUE, M. S. M. The Brazilian genetic resources conservation programm. Archivos de Zootecnia, Córdoba, v. 51, n. 193, p. 39-52, 2002.

FERNÁNDEZ, A.; VIANA, J. L.; IGLESIAS BLANCO, A.; SÁNCHEZ, L. Genetic variability and phylogenetic relationship between ten native catlle breeds from Galicia and the North of Portugal. Archivos de Zootecnia, Córdoba, v. 47, n. 177, p. 61-71, 1998.

GODOI, F. N.; BERGMANN, J. A. G.; ALMEIDA, F. Q.; SANTOS, D. C. C.; MIRANDA, A. L. S.; VASCONCELOS, F. O.; OLIVEIRA, J. E. G.; KAIPPER, R. R.; ANDRADE, A. M. Morphology of Brasileiro de Hipismo foals. Revista Ciência Rural, Santa Maria, v. 43, n. 1, p. 736-742, 2013.

GONÇALVES, R. W.; COSTA, M. D.; ROCH JUNIOR, V. R.; COSTA, M. R.; SILVA, E. S. P.; RIBEIRO, A. M. Inbreeding effect on reproductive traits in a herd of Mangalarga Marchador Brazilian horses. Revista Brasileira de Saúde e Produção Animal, Salvador, v. 12, n. 3, p. 641-649, 2011.

INGLÊS, F. P. D. L. Breed standard. Journal Genética y Mejora Animal, Zaragoza, v. 15, n. 8, p. 197-567, 2004.

JONES, W. E. Genetics and breeding of horses. São Paulo: Roca, 1987. 666 p.

KURTZ FILHO, M.; LÖF, H. K. Biometric in brazilian criollo horse breed. Archives of Veterinary Science, Curitiba, v. 12, n. 1, p. 47-51, 2007.

MAWDSLEY, A.; KELLY, E. P.; SMITH, F. H.; BROPHY, P. O. Linear assessment of the Thoroughbred horse: an approach to conformation evaluation. Equine Veterinary Journal, Cambridgeshire, v. 28, n. 6, p. 461467, 1996.

MCMANUS, C.; FALCÃO, R. A.; SPRITZE, A.; COSTA, D.; LOUVADINI, H.; DIAS, L. T.; TEIXEIRA, R. A.; REZENDE, M. J. M.; GARCIA, J. A. G. Morphological characterization of the Campeiro horse breed. Revista Brasileira de Zootecnia, Brasília, v. 34, n. 5, p. 1553-1562, 2005.

MELO, J. B.; PIRES, D. A. F.; RIBEIRO, M. N. Phenotypic profile in remaining of the Nordestino horse breed from Northeastern of Brazil. Archivos de Zootecnia, Córdoba, v. 62, n. 238, p. 171-180, 2013. 
MELO, J. B.; PIRES, D. A. F.; RIBEIRO, M. N.; SANTOS, D. O.; SILVA, H. G. O. Zoometric study of Nordestino horse breed from Floresta city in Pernambuco state (Brazil). Actas Iberoamericanas de Conservación Animal, Córdoba, v. 1, n. 1, p. 71-74, 2011.

MISERANI, M. G.; McMANUS, C.; SANTOS, S. A.; SILVA, J. A.; MARIANTE, A. S.; ABREU, U. G. P. Evaluation of the factors which influence linear measurement of the Pantaneiro horse. Revista Brasileira de Zootecnia, Brasília, v. 31, n. 1, p. 335-341, 2002.

NASCIMENTO, J. F. Mangalarga marchador: morphological treated. Belo Horizonte: Abccmangalarga Marchador, 1999. 577 p.

OOM, M. M.; FERREIRA, J. C. Biometric study of the Alter horse. Revista Portuguesa de Ciências Veterinárias, Lisboa, v. 83, n. 482, p. 101-148, 1987.

PARÉS i CASANOVA, M. P. Relación entre variables morfométricas encanales de laraza equina "Cavall pirinenc català". Revista Electrónica de Veterinaria, Málaga, v. 11, n. 11, p. 1695-7504, 2010.

PIMENTEL, M. M. L.; CAMARA, F. V.; DANTAS, R. A.; FREITAS, Y. B. N.; DIAS, R. V. C.; SOUZA, M. V. Biometrics of "vaquejada" horses in Rio Grande do Norte, Brazil. Acta Veterinária Brasilica, Mossoró, v. 5, n. 4, p. 376-379, 2011.

PINTO, L. F. B.; ALMEIDA, F. Q.; QUIRINO, C. R. Multivariate analysis of body measures in Mangalarga Marchador foals: discriminant analysis. Revista Brasileira de Zootecnia, Brasília, v. 34, n. 2, p. 600-612, 2005.

POTT, A. Native pastures. Corumbá: EMBRAPA Pantanal, 1997. 161 p. (EMBRAPA-CPAP. Documents: 8).

POTT, E. B.; CATTO, J. B.; BRUM, P. A. R. Periods power critical for bovine in native pasture in Mato Grosso Pantanal. Pesquisa Agropecuária Brasileira, Brasília, v. 24, n. 11, p. 1427-1432, 1989.

QUIRINO, C. R.; MATOS, L. F.; BARTHOLAZZI JUNIOR, A.; CASTRO, T.; SILVA, R. C.; SILVA, J. L. L. Chacterization of Ponies of Brazilian Breed Through linear measures. Actas Iberoamericanas de Conservación Animal, Córdoba, v. 2, n. 1, p. 71-74, 2012.

REZENDE, M. P. G.; RAMIRES, G. G.; SOUZA, J. C. Horses used to pull carts in Aquidauana (MS) are suitable for this purpose ?. Revista Agrarian, Dourados, v. 6, n. 22 , p. 505-513, 2013.
REZENDE, M. P. G.; SOUZA, J. C.; MOTA, M. F.; JARDIM, R. J. D.; RAMIRES, G. G.; SILVA, R. M.; SOUZA, C. F. Equine body morphometry used in work, sport and leisure in three municipalities in Mato Grosso do Sul. Revista Veterinária e Zootecnia, Botucatu, v. 21, n. 4, p. 569-683, 2014.

RODERO, E.; HERRERA, M.; PEÑA, F.; MOLINA, A.; VALERA, M.; SEPÚlVEDA, N. Modelo morfoestructural de los caprinos lecheros españoles florida y payoya en sistemas extensivos. Revista Cientifica, Merida, v. 13, n. 5, p. 403-412, 2003.

SANTOS, S. A. Evaluation and conservation pantaneiro horse in Mato Grosso Pantanal. In: ANNUAL MEETING OF ANIMAL SCIENCE OF BRAZILIAN SOCIETY, 30., 1993, Rio de Janeiro. Anais... Rio de Janeiro: Brazilian Society of Animal Science, 1993. p. 287-308.

SANTOS, S. A.; ABREU, U. G. P.; SOUZA, G. S.; CATTO, J. B. Body condition score, weight variation and reproductive performance of beef cows in rangelands from the Pantanal region. Revista Brasileira de Zootecnia, Brasília, v. 38, n. 2, p. 354-360, 2009.

SANTOS, S. S.; COSTA, C.; SOUZA, G. S.; MORAES, A. S.; ARRIGONI, M. B. Quality of the diet selected by cattle in the Nhecolândia sub-region, Pantanal. Revista Brasileira de Zootecnia, Brasília, v. 31, n. 4, p. 16631673, 2002.

SANTOS, S.A. Recommendations on nutritional management for horses bred in native pastures in the Pantanal. Corumbá: EMBRAPA-CPAP, 1997. 63 p. (EMBRAPA-CPAP. Documents, 22).

SILVA, L. A. C.; SANTOS, S. A.; SIlVA, R. A. S.; McMANUS, C.; PETZOLD, H. Physiological adaptations of the Pantaneiro horse to stress related to daily work with cattle in the Pantanal, Brazil. Archivos de Zootecnia, Córdoba, v. 54, n. 208, p. 509-513, 2005.

THOMAS, H. S. The horse conformation. USA, North Adams: Storey Publishing, 2005. 387 p.

TORRES, A. P.; JARDIM, W. R. Creation of the horse and other horses. São Paulo: Nobel, 1985. 654 p.

VASSILEY, D.; SABEVA, I. Genetic parameters of conformation traits in the East Bulgarian horse. Macedonian Agricultural Review, Macedonia, v. 43, n. 1-2, p. 41-44, 1996.

ZÚCCARI, C. E. S. N.; NUNES, D. B.; CORRÊA FILHO, R. A. C. Reproductive eficiency in Pantaneira mares during breeding season 1995/2000. Archivos de Zootecnia, Córdoba, v. 51, n. 193, p. 139-148, 2002. 